\title{
ENERGY SECURITY AND ENERGY EFFICIENCY ISSUES: HOUSEHOLD PERSPECTIVE IN EUROPEAN COUNTRIES
}

\author{
Manuela Tvaronavičienè \\ Department of Economics and Management of Enterprises, Faculty of Business Management, \\ Vilnius Gediminas Technical University, Saulètekio 11, LT-10223, Vilnius, Lithuania \\ E-mail: manuela.tvaronaviciene@vgtu.lt
}

\begin{abstract}
Aim of presented paper is provide the latest approaches towards energy security, to examine methodological foundations used, and to contribute to the contemporary discussion by providing new insights stemming from emerging needs of enhancing energy security. In the presented paper a role of energy efficiency among other constituents of energy security is being discussed. The second - analytical part of paper is devoted to forecasting of long-term (until year 2050) energy intensities in household sectors in the following countries: Lithuania, Estonia, Belgium, Germany, Luxemburg and Bulgaria. Author claims, that revealed differences provide theoretically grounded foundations for further benchmarking of energy intensities.
\end{abstract}

Keywords: energy security, energy efficiency, energy intensity, household sector, European countries, consumption.

JEL Classification: O10; O3.

\section{Introduction}

Concern about energy security is has been growing recent decades and it seems, there still are no objective reasons to erase this issue from a list of the most urgent problems. Increasing consumption and devastation of natural nonrenwable energy resources threatens sustainability of our planet in long run. In order to enhance independence of businesses and ordinary people from availability of energy resurces and increase affordability, energy security facets have to be indicated, tendencies revealed, analysed, threats predicted and respective polict implications formulated.

The presented paper aims to reveal what are long-term tendencies of energy consumption in household sector of differently developed European countries. Assumption of diminishing energy consumption is being tackled and availability of consistent patterns of energy use as countries develop are being checked.

\section{Energy security perception}

Energy security is complex phenomenon. We believe that success of efforts directed to energy security enhancement depends on energy security perception and respective indication of its constituents. In order to review current approaches towards energy security let us immerse ourselves into ongoing discussion about energy security definition.
Here it is important to draw an attention to the scope of literature under review: we concentrate on the very latest papers in the area, which were published in years 2013, 2014 and 2015, and only few relevant papers, older than three years will be referred where relevant.

We will start review by providing comments on a paper "The concept of energy security: beyond four A" by Cherp and Jewell (Cherp, Jewell 2014). We have chosen this paper as the starting point of energy security conceptualization for the following reason. Authors of this paper at the very beginning of their article very clearly indicate that "energy security should be conceptualized as instance of security in general" (Cherp, Jewell 2014). This approach is absolutely compliant with our approach. We believe that energy security should be conceptualized perceiving it as constituent of security. Since security is very closely related to sustainable development (Vosylius et al. 2013; Shadova et al. 2015; Białoskórski 2012) we need to distinguish what energy security facets are the most important, evaluating this importance from the prospective of security and sustainable development enhancement. At this point we wanted to make brief excurse to sustainable development area. By now sustainable development is being understood mainly as sustainable economic development, which means sequent and gradual moving towards countries welfare through better education, diminishing of extreme inequality, better perfor- 
mance of institutions etc., and of course, not losing from focus environmental issues of development. Energy security, and, more jenerally, security in his constexts appears to be rather new concept analyzed in economic context. We claim, that insecurity, energetic insecurity in our analyzed case is closely related to long-term competitiveness of countries. Long-term competitiveness could be achieved only through smart solutions (Prause 2015), new behavioral patterns (Rosha, Lace 2015) which orient to efficien use of scare resources, and especially non-renewable ones.

Authors of above mentioned paper (Cherp, Jewell 2014) underline the following questions, which should be addressed by concept of energy security: "Security for whom?", "Security for which values?" and "Security from what threats?". Admitting importance of these questions, authors are more inclined to use, as they call "influential approach - the 'four As of energy security' (availability, accessibility, affordability, and acceptability)" (Cherp, Jewell 2014).

Here width and complexity of the area, within which eclectic energy security facets are being indicated, protrudes. It is obvious, that security facets ("security for whom", "security from what threats") are being intertwined with generic sustainable development facets: "security for which values", and all four authors' as: availability, accessibility, affordability and acceptability. Distinguished facets of energy security partially overlap: "security for which values" and "acceptability" are dependent on energy policies, which again, could be estimated only after agreeing what common methodological platform is acceptable for all discussing parties. Here we need to mention, that energy security facets were transforming over time.

Basing on the scientific literature authors (Cherp, Jewell 2014) draw attention into different periods, characterized by different contexts of energy security perception. One, early period, dates back to age of oil prices in 1970s. 2000s are indicated as another period, which is characterized by issues of different origin. Increasing demand of oil in Asia, Europe's dependency on gas and environmental degradation due to increase in energy use become problems under consideration. Hence energy availability represents the classical, or early characteristics of energy security, while affordability and acceptability may be conditionally called "new" characteristics, which are introduced in attempt to address contemporary issues of global development, such as increasing demand of energy, triggered by increasing population and respective increase of economic activities, and consequent environmental degradation (Dudzevičiūtė 2012; Tvaronavičienè 2012, 2014; Antanavičienè 2014; Balitskiy et al. 2014; Balkytè, Tvaronavičienè 2010; Bilevičienè, Bilevičiūtè 2015; Caurkubule, Rubanovskis 2014; Corneliu, Tamošiūnienè 2015; Dezellus et al. 2015; Lapinskienè et al. 2014, 2013; Peker et al. 2014; Rakauskienè 2014; Vosylius et al. 2013; Tvaronavičienè et al. 2014; Raudeliūnienè et al. 2014; Jefremov, Rubanovskis 2015; Vasiliūnaitè 2014; Bistrova et al. 2014; Borshchevska 2015).

The complexity of energy security conceptualization due to its close relation to security, economic growth and sustainable development issues caused intensive discussions about energy security dimensions, which are reflected in ample sources e.g. (Vosylius et al. 2013; Tvaronavičienè 2014; Tvaronavičius, Tvaronavičiene 2008; Scaringelli 2014; Miškinis et al. 2013; Travkina, Tvaronavičienè 2015). The way how researchers, politicians and other stakeholders introduce new dimensions is vividly described in recent paper titled "Three blind men and an elephant: The case of energy indices to measure energy security and energy sustainability" (Narula, Reddy 2015): "The paper compares three different indices 'Energy Sustainability Index', 'International Index of Energy Security Risk' and 'Energy Architecture Performance Index' along with their variants to examine if they provide consistent results for various countries. A comparative assessment reveals that the three indices provide different country rankings, which are inconsistent. This situation is akin to three blind men groping the elephant with each one measuring a different part of the body and asserting that only their assessment is true" (Narula, Reddy 2015). Here we neeed to note, that energy security facets have to be discussed further, in order they could be measured and controlled. We suggest that indicators energy efficiency in various sectors have to be discussed and highlighted as being considerably important to be monitored. Energy efficiency depends of approaches and hehavioral patterns. Hence we believe that energy efficiency and energy use patterns are the most vividly reflected by household sector. Therefore in this paper we tackcle household sector energy intensities in differently developed European countries.

Before we go to this analysis, let us take a grance at variety of energy security facets, suggested by other authors. In Table 1 we provide egzample of main aspects of another approach to energy security. We believe that all those facets, mentioned by various authors should be ultimately taken into account. 
Table 1. Main aspects evaluated (Source: Månsson et al. 2014)

\begin{tabular}{l|l|l|l}
\hline Upstream markets and imports & $\begin{array}{l}\text { Domestic markets } \\
\text { and infrastructure }\end{array}$ & Economic vulnerability & Integrated methods \\
\hline $\begin{array}{l}\text { Reliability, resilience, and robust- } \\
\text { ness of infrastructure }\end{array}$ & $\begin{array}{l}\text { Reliability, resili- } \\
\text { ence, and robustness } \\
\text { of infrastructure }\end{array}$ & $\begin{array}{l}\text { Welfare loss from high or } \\
\text { volatile prices }\end{array}$ & $\begin{array}{l}\text { Holistic supply chain } \\
\text { security/security of } \\
\text { energy services }\end{array}$ \\
\hline $\begin{array}{l}\text { Systematic and specific riskRelia- } \\
\text { bility of suppliers and supply routes }\end{array}$ & & $\begin{array}{l}\text { Economic consequences } \\
\text { of resource scarcity }\end{array}$ & $\begin{array}{l}\text { Spatial and/or temporal } \\
\text { comparisons of security }\end{array}$ \\
\hline & $\begin{array}{l}\text { Outage cost from power dis- } \\
\text { ruptions }\end{array}$ & \\
\hline
\end{tabular}

We think that additional dimensions should be added: behavioral practices, leadership, education, absorptive capacity (like in technology transfer), sustainable law, safety of society, literacy, awareness (Dudzevičiūtè et al. 2014; Njaramba et al. 2015; Tvaronavičienè et al. 2015).

Approach top-down should be combined with bottom-up. As survey shows, exporting companies do not care much about long term prospective. Users have to share responsibility by sharing responsibility for energy security. Hence, indexes one or another have to incorporate human behavior constituent.

Here it is needed to point out, that energy security issues embraces many sciences, economics, management, engineering, and even sociology. Efficiency of energy use, which is reflected by energy intensity indicator, is affected by multiple factors, which in their turn can be elaborated by within framework of all disciplines listed above. Further we will turn to our analytical part, which is done by employing econometric tools and comparative analysis, and is attributed to research area of economics.

\section{Forecast and comparative analysis of final energy intensities of households in selected countries}

Sections should not be numbered. In general, after the abstract the background and the purpose of the study should be stated first in the introduction, followed by sections in which details of the methods, materials, procedures, and equipment used should be described. Discussion and conclusions should follow. The reference list must be provided at the end of the document. Appendices may be employed if appropriate.

\subsection{Research methodology}

Energy intensity of final energy consumption considerably depends on demand, which stems from activity of households, mainly in the area of heating and cooling, and activities of agriculture, industry, services and mode of transportation. In order to manage demand, we need to estimate, forecast and benchmark energy intensity in listed above areas. Since households' activity affects all areas of life, we will tackle households' final energy consumption in differently developed countries.

If we managed to benchmark correctly energy intensity for households we could ultimately finish with more favorable energy balance. We are assuming that forecasted in long-term energy intensity in developed countries would allow us to set target for less developed countries. This assumption is based on economic law of universal converging. Besides we assume that energy efficiency would gradually increase, and respectively energy intensity would diminish due to technological progress and energy stewardship behavior (Tvaronavičienè 2012; Dudzevičiūtè et al. 2014; Tvaronavičienè et al. 2015; Laužikas et al. 2015, Grubicka, Matuska 2015; Ala-Juusela et al. 2014; Dzemyda, Raudeliūnienè 2014; Dobele et al. 2015; Olaniyi, Reidolf 2015; Oganisjana, Surikova 2015; Tvaronavičienè, Černevičiūtè 2015; Leonavičius et al. 2015; Baublys etal. 2015; Ignatavičius et al. 2015).

For forecasting of energy intensities we will use rather unique modelling tool: The Long-range Energy Alternatives Planning system (LEAP) is a widely-used software tool for energy policy analysis and climate change mitigation assessment developed at the Stockholm Environment Institute (SEI). It has been adopted by thousands of organizations in more than 190 countries worldwide. Its users include government agencies, academics, non-governmental organizations, consulting companies, and energy utilities, and it has been used at scales ranging from cities and states to national, regional and global applications. (LEAP web site: www.energycommunity.org)

We will use LEAP software for long-range forecasting purposes, despite this tool provides 
much possibilities, which reach much farer than the forecasting, such as modelling of activity levels and energy intensities under different conditions, such as GDP growth, changed structures of economies of selected countries, energy mix and etc. Here we assume, that modelling is relevant and reasonable only after forecasting of selected indicators is performed and comparative analysis of obtained results is being done and economically interpreted. The tool selected for analysis provides possibilities to forecast using real data or to choose scenario (e.g. mitigation), which assumes conditions in the future would change. Again, we claim that it is reasonable to elaborate scenarios, other than ceteris paribus only after energy intensities under unchanged conditions are being juxtaposed and tendencies of such in a long-run revealed.

Let us stop on time frame of forecasting. Usually we distinguish the following time perspectives used for forecasting: short-term (one year), medium (up to five years); mezzo (up to 10-15 years) and long term (up to 50 years). Actually, time periods, longer than 15 years are already considered as being long-term. In our case, we will be tackling results of forecasting, embracing year 2050; it means we will deal with extremely long period, what would ultimately allow to purify tendencies, which, actually, are set by historical and current economic data. Here it is important to note, that the modelling tool, we are going to employ does not require data input, but operates on data, which are already extract from relevant databases and reach back to year 1990 .

\subsection{Research limitation}

In our forecasting we will rely on baseline scenario, what means, that we assume, that current conditions would be valid for all years up 2050. Of course, in reality conditions might change, but adopting ceteris paribus assumption is valuable from the following point of view: we are getting results, which would occur if there no cardinal changes in approaches towards energy consumption take place. Therefore need for changes can be estimated.

\section{Analysis and results}

The following countries have been selected for energy intensity analysis: Lithuania, Estonia, Bulgaria, Belgium, Germany and Luxemburg. Selection of those countries has been made basing on provided arguments. Lithuania and Estonia are similar countries in terms of geographical location, history and level of economic development. Bulgaria has been selected as country, which is among the weakest among European Union members judging from the point of view of statistically measured economic development. Belgium, Germany and Luxemburg represent the richest the EU countries. Those three countries has been selected with a purpose to observe if consistent patterns can be traced; i.e. to verify, if forecasted energy intensities can be characterized by the same trends of change, and if countries' size and economic specialization affect trends, which will be revealed in result of analysis At first let us clarify how much selected countries differ by energy consumption level at the current moment. For the current moment we will take forecasted energy intensity in household sector for year 2017. Differences we will reflect graphically (Fig. 1).

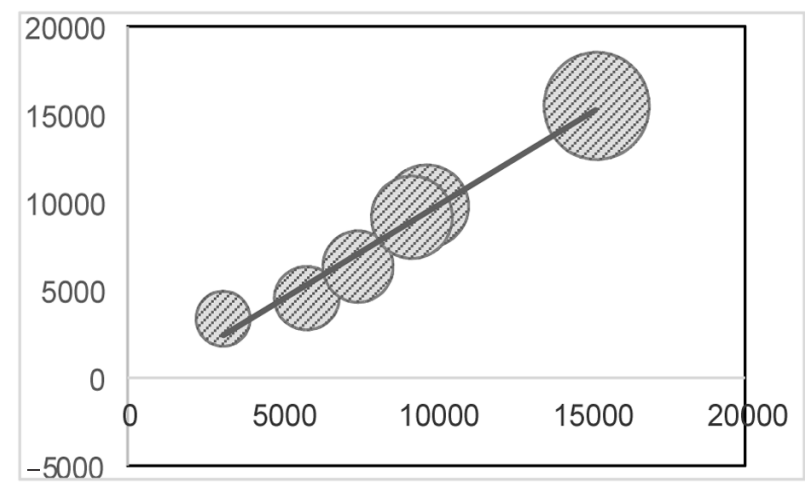

Fig. 1. Distribution of forecasted energy intensities in household sector, year 2017 (in Kilowatt-hour per Person) (Source: author)

Hence, in Figure 1 range of forecasted energy intensities in household sector is presented for year 2017. It is obvious that selected countries could be characterzed like considerably differing in energy use in household sector.

What is peculiar about the energy intensities, that more developed countries appear to be much more intensive in household sector. Meanwhile, according assumption raised, better developed countries have to be less energy intensive due to the newest energy saving technologies used and state policies oriented to energy stewardship. Here, data witness that less developed countries are less energy intensive; their consumption patterns affect energy security state less if to compare to highly developed countries. Another moment, which needs to be emphasized is range of difference observed: it appears that such country as Lithuania is almost three times less energy intensive in household sector if to compare to e.g. Luxemburg. 
In Table 2 forecasted energy intensities for selected countries are presented. We have possibility to observe tendencies of energy intensities change and to make conclusions about behavioral patterns of households in energy use. Despite significant decrease of energy intensities, especially in highly developed countries, is expected, forecasted data does not allow to verify such expectation. It appears that energy intensities in Belgium, Germany and Luxemburg remain high, and diminishing tendency does not exist. The tendencies of energy consumption could not be positively evaluated, since they tend to enhance energy insecurity, and are detrimental to secure sustainable development aim.

As it was mentioned above, secure sustainable development has to be associated with long-term competitiveness. Long-term competitiveness could not be imagined without efficient use of scare resources, and especially non-renewable ones. Renewable energetic resources by now comprise still very small fraction of energy mix. Even in case of increase of share of renewable energy sources, energy intensity issues will not become less urgent. Hence, decrease of energy efficiency has to be indicated as one of preconditions and driving factors of sustainable long-term competitiveness. In that context comparison of forecasted energy intensities in household sector of selected countries becomes very important since lets us observe bottlenecks for long-term secure and sustainable economic development compatible with reduced energy consumption taken per Person).

Let us take a closer look at forecasted energy intensities at selected countries. Hence Lithuania's data of households' energy intensity forecast suggest that energy intensity would growth: at the current moment energy intensity is around $4.5 \mathrm{Ki}$ lowatt- Hour per Person, in year 2050 it would be 5.7 Kilowatt- Hour per Person. This tendecy is oposit to rational expectations of gradual diminishing of inergy intensities in all sectors of economy, including households. It is rather unexpected, that in year 2050, which should be marked by new smart technologies we would find ourselves at levels on energy intensity, which was recorded in year 1990. It is supposed, that a reason of this phenomenon migh lie in increased number and variety of devises, wchich households will use in year 2050.

Forecasted energy intensity of Estonia's households forecasted until year 2050 is rather similar, what allows us to claim, that forecasted energy intensities let us reveal a tendency, which is rather common for this particular level of development.
Nevertheless, absolute value of households' energy intensity is significantly higher.

Bulgaria has been chosen for comparison purposes because of its relatively lower lever of development: we had an intension to check whether Bulgaria's indicator would be similar to Lithuania's and Estonia's. It appeared, that differently than in Lithuania and Estonia (where energy intensities of households' activity in year 2050 remained at a level of 1990), in Bulgaria households' energy intensity demonstrates gradual growth. Despite this growth energy intensity level remains rather low if to compare it to Lithuania, and Estonia.

Cases of Belgium, Germany and Luxembourg provide us with additional evidences of nondiminishing energy intensities in the area of household consumption.

To conclude, the results of forecasting provide us rather unexpected and very interesting from scientific point of view results: in a year 2050 Lithuania energy intensity measured in kilowatt hour per person will be 5730. 2, in Estonia 7184.2, in Bulgaria 4374.9, in Belgium and Germany respectively 9000.7 and 9000.7 and in Luxembourg will reach striking heights of 15000.2 kilowatt hour per person.

In Table 2 for corparison reasons data of energy intensities in household sectors of our target countries are provided for year 1990, 2017 and 20150. Those years are supposed to reflect historic data, current state and lon-term prospective.

Table 2. Energy intensities in analyzed countries, in Kilowatt-hour per Person, in year 1990 year 2017 (forecasted) and year 2050 (forecasted) (Source: author)

\begin{tabular}{l|c|c|c}
\hline Countries & $\begin{array}{c}\text { Energy } \\
\text { intensity, } \\
\text { year 1990 }\end{array}$ & $\begin{array}{c}\text { Energy } \\
\text { intensity, } \\
\text { year 2017 }\end{array}$ & $\begin{array}{c}\text { Energy } \\
\text { intensity, } \\
\text { year 2050 }\end{array}$ \\
\hline Lithuania & $5796 \mathrm{~s}$ & 4461 & 5730 \\
\hline Estonia & 7489 & 6283 & 7184 \\
\hline Bulgaria & 3115 & 3313 & 4375 \\
\hline Belgium & 9700 & 9800 & 9700 \\
\hline Germany & 9200 & 9100 & 9500 \\
\hline Luxemburg & 15200 & 15500 & 15200 \\
\hline
\end{tabular}

Energy intensities in currently less developed countries does not increase, except of Bulgaria. In Lithuania and Estonia energy intensities diminish slightly.The obtained results signal about inefficiency of policies oriented to energy stewardship, especially in developed countries, which obviously 
are used to excessive counsumption brought by favourable economic development decades.

In order to have a more clear view of character of energy internsity changes in selected countries respective each other we will provide forecasted data of energy intensities in selected countries in year 1990, year 2017, and in year 2050 (Fig. 2).

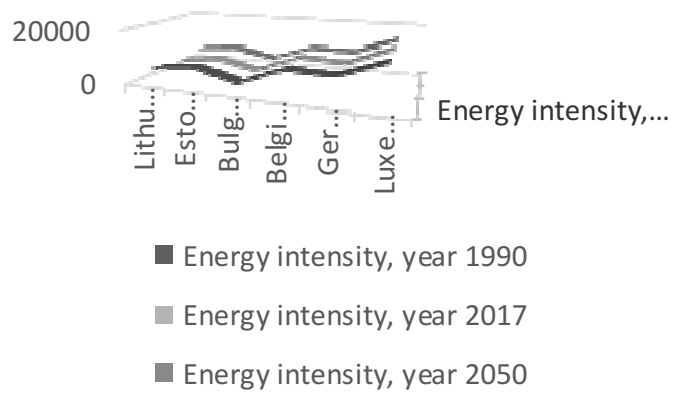

Fig. 2. Tendencies of energy intensities in household sector change in selected countries in lon-term; i.e, until year 2050 (Source: author)

Graphically reflected tendencies of energy intensities in household sector change in selected countries in lon-term; i.e, until year 2050 allow to conclude that better developed countries remain extremely energy intensive, what is detrimental to processes on secure sustainable development and hinder seeking and maintaining competitiveness in long-run. This insight could be formulated and in a different way: household behavior, determined by ample well-being of developed countries is does not oriented to energy stewardship but rather is oriented to opposite direction, i.e. to ample unrestricted use of wide range of devises. It is obvious that technologic adwance can absorb this kind of behavior only partly since energy intensities are not going to diminish. The whole progress in energy intensity diminishing process demonstrates rather limited results and is restricted to curbing energy intensity growth. It is peculiar that very similar tendencies are observed in all countries, irrespective of level of their development. That leads to assumption that currently less developed European countries in future may obtain certain competitive advantage over old European countries in the field of energy intensity, i.e. energy usage pattern. Here let us point out to the importance of household sector, which is determined by its considerable share in the whole energy consumption in each country, and the fact that energy consumption patterns in household sector are naturaly transferred to other sectors of economy.

\section{Conclusions}

The presented paper argues, that energy security has to be perceived as constituent of security of countries and individuals. Security in its own turn serves as one of preconditions of sustainable development. Long-term secure sustainable development could be achieved only by involving individuals and organizations into process of energy stewardship and so gradually shifting self-perception from energy security observers to energy security enhancers. Basing on the performed analysis the following insights can be formulated. The first, energy intensity of households in the long run is not going to diminish. That tendency has to be taken into account and interpreted as conditional threat, which can undermine energy security in the future. The second, proactive policy in energy consumption area is urgent, otherwise energy stewardship culture is difficult to implement. The third, we suggest strengthen benchmarking attempts. Energy intensity in household sector could be benchmarked by considerably lower intensity than demonstrates higly developed European coutries. Revealed trends and concrete results can be followed by respective policy implications in the area of energy use. Diminishing of consumption and respective diminishing of energy intensities in developed countries have to be set as target tackled by economic policies introduced.

\section{Disclosure statement}

Author declares that she does not have any competing financial, professional, or personal interests from other parties.

\section{References}

Ala-Juusela, M.; Short, M.; Shvadron, U. 2014. Tools to support sustainable entrepreneurship in energy positive neighbourhoods, Entrepreneurship and Sustainability Issues 2(2): 49-59. http://dx.doi.org/10.9770/jesi.2014.2.2(1)

Antanavičienè, J. 2014. Foreign direct investment: driving factors and outcomes for secure and sustainable development, Journal of Security and Sustainability Issues 3(3): 55-67. http://dx.doi.org/10.9770/jssi.2014.3.3(5)

Balitskiy, S.; Bilan, Y.; Strielkowski, W. 2014. Energy security and economic growth in the European Union, Journal of Security and Sustainability Issues 4(2): 123-130. http://dx.doi.org/10.9770/jssi.2014.4.2(2)

Balkyte, A.; Tvaronavičiene, M. 2010. Perception of competitiveness in the context of sustainable development: facets of "sustainable competitiveness", 
Journal of Business Economics and Management 11(2): 341-365.

Baublys, J.; Miškinis, V.; Konstantinavičiūtè, I.; Lekavičius, V. 2015. Energy efficiency as precondition of energy security, Journal of Security and Sustainability Issues 4(3): 197-208.

http://dx.doi.org/10.9770/jssi.2015.4.3(1)

Białoskórski, R. 2012. Cyberthreats in the security environment of the $21^{\text {st }}$ century: attempt of the conceptual analysis, Journal of Security and Sustainability Issues 1(4): 249-260. http://dx.doi.org/10.9770/jssi.2012.1.4(2)

Bilevičienè, T.; Bilevičiūtè, E. 2015. Influence of employment on strategy of sustainable development implementation, Journal of Security and Sustainability Issues 4(3): 520-535. http://dx.doi.org/10.9770/jssi.2015.4.3(3)S

Bistrova, J.; Lace, N.; Tvaronavičienè, M. 2014. Corporate governance as a crucial factor in achieving sustainable corporate performance, Journal of Systemics, Cybernetics and Informatics 12(3): 82-90.

Borshchevska, Y. 2015. Path to sustainability. Troubled gradualism of the unfinished coal minining reform in Ukraine, Journal of Security and Sustainability Issues 4(4): 323-343.

http://dx.doi.org/10.9770/jssi.2015.4.4(2)

Caurkubule, Ž.; Rubanovskis, A. 2014. Shadow economy as an obstacle to sustainable economic development, Journal of Security and Sustainability Issues 4(2): 175-186. http://dx.doi.org/10.9770/jssi.2014.4.2(6)

Cherp, A.; Jewell, J. 2014. The concept of energy security: beyond the four As, Energy Policy 75: 415-421.

Corneliu, M.; Tamošiūnienè, R. 2015. Modern approaches in quantifying economic security: case sudy of Estonia, Latvia, Lithuania and Republic of Moldova, Journal of Security and Sustainability Issues 4(4): 596-610. http://dx.doi.org/10.9770/jssi.2015.4.4(2)S

Dezellus, E.; Ferreira, L.; Pereira, N.; Vasiliūnaitè, R. 2015. Entrepreneurship conditions: energy resources, prices and energy consumprion peculiarities in developed countries, Entrepreneurship and Sustainability Issues 2(3): 163-170. http://dx.doi.org/10.9770/jesi.2014.2.3(5)

Dobele, L.; Grinberga-Zalite, G.; Kelle, L. 2015. Sustainable economic development: scenarios for promotion of social innovation in Latvia, Journal of Security and Sustainability Issues 5(2): 149-158.

Dudzevičiūtè, G. 2012. Conceptual approaches towards sustainability, Journal of Security and Sustainability Issues 1(4): 261-272. http://dx.doi.org/10.9770/jssi.2012.1.4(3)

Dudzevičiūtè, G.; Mačiulis, A.; Tvaronavičienè, M. 2014. Structural changes of economies: Lithuania in the global context, Technological and Economic Development of Economy 20(2): 353-370.
Dzemyda, I.; Raudeliūnienè, J. 2014. Sustainable youth entrepreneurship in conditions of global economy toward energy security, Entrepreneurship and Sustainability Issues 1(4): 247-256. http://dx.doi.org/10.9770/jesi.2014.1.4(7)

Grubicka, J.; Matuska, E. 2015. Sustainable entrepreneurship in conditions of UN (Safety) and technological convergence, Entrepreneurship and Sustainability Issues 2(4): 188-197. http://dx.doi.org/10.9770/jesi.2015.2.4(2)

Ignatavičius, R.; Tvaronavičienè, M.; Piccinetti, L. 2015. Sustainable development through technology transfer networks: case of Lithuania, Journal of Security and Sustainability Issues 4(3): 261267. http://dx.doi.org/10.9770/jssi.2015.4.3(6)

Jefremov, V.; Rubanovskis, A. 2015. Towards a sustainable Latvian energy resources and energy markets in the context of the EU, Journal of Security and Sustainability Issues 4(3): 552-563. http://dx.doi.org/10.9770/jssi.2015.4.3(5)S

Lapinskienè, G.; Tvaronavičienè, M.; Vaitkus, P. 2014. Greenhouse gases emissions and economic growth - evidence substantiating the presence of environmental Kuznets curve in the EU, Technological and Economic Development of Economy 20(1): 65-78. http://dx.doi.org/10.3846/20294913.2014.881434

Lapinskienè, G.; Tvaronavičienè, M.; Vaitkus, P. 2013. The analysis of the validity of environmental Kuznets Curve for the Baltic States, Environmental and Climate Technologies 12: 41-46.

Laužikas, M.; Tindale, H.; Tranavičius, L.; Kičiatovas, E. 2015. Effects of consumer behaviour on innovations in fast food industry, Entrepreneurship and Sustainability Issues 3(1): 85-104. http://dx.doi.org/10.9770/jesi.2015.3.1(1)

Leonavičius, V.; Genys, D.; Krikštolaitis, R. 2015. Public perception of energy security in Lithuania, Journal of Security and Sustainability Issues 4(4): 311322. http://dx.doi.org/10.9770/jssi.2015.4.4(1)

Månsson, A.; Johansson, B.; Nilsson, L. J. 2014. Assessing energy security: an overview of commonly used methodologies, Energy 73: 1-14.

Miškinis, V.; Baublys, J.; Lekavičius, V.; Morkvėnas, A. 2013. New changes in Lithuanian energy sector, Journal of Security and Sustainability Issues 2(3): 15-28. http://dx.doi.org/10.9770/jssi.2013.2.3(2)

Narula, K.; Reddy, B. S. 2015. Three blind men and an elephant: the case of energy indices to measure energy security and energy sustainability, Energy 80: $148-158$.

Njaramba, J.; Chigeza, P.; Whitehouse, H. 2015. Financial literacy: the case of migrant African-Australian women entrepreneurs in the cairns region, Entrepreneurship and Sustainability Issues 3(2): 198-208. http://dx.doi.org/10.9770/jesi.2015.3.2(7) 
Oganisjana, K.; Surikova, S. 2015. Social innovation in the promotion of sustainable development of the contemporary Latvian society, Journal of Security and Sustainability Issues 5(2): 249-258. http://dx.doi.org/10.9770/jssi.2015.5.2(10)

Olaniyi, E. O.; Reidolf, M. 2015. Organisational innovation strategies in the context of smart specialization, Journal of Security and Sustainability Issues 5(2): 213-227. http://dx.doi.org/10.9770/jssi.2015.5.2(7)

Peker, S.; Tvaronavičienè, M.; Aktan, B. 2014. Sustainable risk management: fuzzy approach to volatility and application on FTSE 100 Index, Entrepreneurship and Sustainability Issues 2(1): 30-36. http://dx.doi.org/10.9770/jesi.2014.2.1(4)

Prause, G. 2015. Sustainable business models and structures for industry 4.0, Journal of Security and Sustainability Issues 5(2): 159-169. http://dx.doi.org/10.9770/jssi.2015.5.2(3)

Rakauskienè, O. G. 2014. Long term changes in the quality of life of Lithuanian population: 20 years in the market economy, Journal of Security and Sustainability Issues 4(1): 41-58. http://dx.doi.org/10.9770/jssi.2014.4.1(4)

Raudeliūnienè, J.; Tvaronavičienè, M.; Dzemyda, I.; Sepehri, M. 2014. Sustainable entrepreneurship through energy stewardship: role of values and behavioral patterns, Entrepreneurship and Sustainability Issues 2(2): 107-117.

Rosha, A.; Lace, N. 2015. Sustainable development of organizations: coaching for innovation accelerating, Journal of Security and Sustainability Issues 5(2): 171-180. http://dx.doi.org/10.9770/jssi.2015.5.2(4)

Scaringelli, M. A. 2014. Are the foreign controlled firms more environmentally sustainable than domestically controlled ones?, Journal of Security and Sustainability Issues 4(2): 131-146. http://dx.doi.org/10.9770/jssi.2014.4.2(3)

Shadova, Z.; Tappaskhanova, E.; Abrhám, J.; Zumakulova, Z. 2015. Tourism security and sustainability: a case study of north Caucasus region, Journal of Security and Sustainability Issues 4(3): 509519. http://dx.doi.org/10.9770/jssi.2015.4.3(2)S
Travkina, I.; Tvaronavičiene, M. 2015. Peculiarities of export structure in Lithuania: synthesis and analysis, Entrepreneurship and Sustainability Issues 2(4): 233-247. http://dx.doi.org/10.9770/jesi.2015.2.4(7)

Tvaronavičienè, M. 2012. Contemporary perceptions of energy security: policy implications, Journal of Security and Sustainability Issues 1(4): 235-247.

Tvaronavičienè, M. 2014. If industrial sector development is sustainable: Lithuania compared to the EU, Entrepreneurship and Sustainability Issues 1(3): 134-142. http://dx.doi.org/10.9770/jesi.2014.1.3(2)

Tvaronavičienè, M.; Černevičiūtè, J. 2015. Technology transfer phenomenon and its impact on sustainable development, Journal of Security and Sustainability Issues 5(1): 87-97. http://dx.doi.org/10.9770/jssi.2015.5.1(7)

Tvaronavičienè, M.; Mačiulis, A.; Lankauskienė, T.; Raudeliūnienè, J.; Dzemyda, I. 2015. Energy security and sustainable competitiveness of industry development, Ekonomska Istrazivanja - Economic Research 28(1): 502-516.

Tvaronavičienè, M.; Šimelytè, A.; Lace, N. 2014. Sustainable development facets: exporting industrial sectors from inside, Journal of Security and Sustainability Issues 3(4): 37-44. http://dx.doi.org/10.9770/jssi.2014.3.4(4)

Tvaronavičius, V.; Tvaronavičiene, M. 2008. Role of fixed investments in economic growth of country: Lithuania in European context, Journal of Business Economics and Management 9(1): 57-64.

Vasiliūnaite, R. 2014. Sustainable development: methodological approaches toward issues, Journal of Security and Sustainability Issues 3(3): 69-75. http://dx.doi.org/10.9770/jssi.2014.3.3(6)

Vosylius, E.; Rakutis, V.; Tvaronavičienè, M. 2013. Economic growth, sustainable development and energy security interrelations, Journal of Security and Sustainability Issues 2(3): 5-14. http://dx.doi.org/10.9770/jssi.2013.2.3(1) 